\title{
Article \\ Use of Sentinel-2 Satellite for Spatially Variable Rate Fertiliser Management in a Sicilian Vineyard
}

\author{
Antonio Comparetti ${ }^{1, *(1)}$ and Jose Rafael Marques da Silva ${ }^{2,3}$ \\ 1 Department of Agricultural, Food and Forest Sciences, University of Palermo, Viale delle Scienze, \\ Building 4, 90128 Palermo, Italy \\ 2 Mediterranean Institute for Agriculture, Environment and Development (MED), \\ Department of Rural Engineering, School of Science and Technology, University of Évora, \\ 7000-671 Évora, Portugal; jmsilva@uevora.pt \\ 3 Agroinsider Lda., PITE, R. Circular Norte, NERE, Sala 18, 7005-841 Évora, Portugal \\ * Correspondence: antonio.comparetti@unipa.it
}

check for updates

Citation: Comparetti, A.; Marques da Silva, J.R. Use of Sentinel-2 Satellite for Spatially Variable Rate Fertiliser Management in a Sicilian Vineyard. Sustainability 2022, 14, 1688. https:// doi.org/10.3390/su14031688

Academic Editor:

Helvi Heinonen-Tanski

Received: 29 December 2021

Accepted: 29 January 2022

Published: 1 February 2022

Publisher's Note: MDPI stays neutral with regard to jurisdictional claims in published maps and institutional affiliations.

Copyright: (c) 2022 by the authors. Licensee MDPI, Basel, Switzerland. This article is an open access article distributed under the terms and conditions of the Creative Commons Attribution (CC BY) license (https:// creativecommons.org/licenses/by/ $4.0 /)$.

\begin{abstract}
Satellites can be used for producing maps of within-field crop and soil parameters and, consequentially, spatially variable rate crop input application maps. The plant vegetative vigour index (i.e., Normalised Difference Vegetation Index-NDVI) and the leaf water content index (i.e., Normalised Difference Water Index-NDWI) maps were used to study-through both time and space- the phenological phases of two plots, with Syrah and Nero d'Avola grapevine varieties, in a Sicilian vineyard farm, located in Naro (Agrigento, Sicily, Italy). The aim of this work is to produce spatially variable rate nitrogen fertiliser maps to be applied in the two vineyard plots under study as well as to understand when they should be fertilised or not according to their target crop yields. The average plant vegetative vigour and leaf water content of both the plots showed a high temporal and spatial variability during all phenological phases and, according to these results, the optimal fertilisation time should have been 12 April 2021. In fact, this crop operation is aimed at supporting the vegetative activity but must be performed when the soil water and, therefore, the plant leaf water content are high. Therefore, spatially variable rate fertilisation should have been performed around 12 April 2021 in both plots, using previous NDVI maps and taking into consideration two management zones. This work demonstrates the usefulness of remote sensing data as Decision Support Systems (DSS) for nitrogen fertilisation in order to reduce the production cost, environmental impact and climate footprints per kg of produced grapes, according to the European Green Deal challenges.
\end{abstract}

Keywords: precision viticulture; remote sensing; temporal variability; spatial variability; nitrogen spatially variable rate fertilisation; sustainable vineyard management

\section{Introduction}

Food production is paramount for everybody, and producing food in a cost-effective way is the goal of any farmer, large-scale farm manager and regional agricultural agency. A farmer needs to be informed in order to be efficient; he must know information about his products in order to forge a viable strategy for crop operations. These tools will help him understand the soil parameters, potential yield, crop health and the extent of eventual diseases and/or stress damages. Commodity brokers are also very interested in how well farmers are producing, as crop yield (both quantity and quality) estimates all products control price and worldwide trade.

Moreover, spatial variability in vineyards is an important issue that affects both farmers and winemakers, especially when trying to obtain the best potential from their vines. Land (topography and soil), climate and diseases affect crop development and, therefore, grape yield and quality in a vineyard. Some of these factors of spatial variation remain stable over time. The study of these factors can lead winemakers to better understand 
the different qualities of batches, in order to plan different processing procedures and, therefore, obtain a higher profit from the grapes. Furthermore, this information allows spatially variable rate application of crop inputs (water, fertilisers, herbicides and pesticides) and operations (pruning, shoot and grape thinning and canopy management), with the aim of achieving more uniform parcels. A high yearly within-field spatial variability, found by some scientists, shows the great importance of differential management and selective harvest [1-3].

The applications of remote sensing [4] to agriculture include crop type (i.e., plant species) mapping; crop condition assessment; crop yield estimation; mapping of soil parameters and crop operations (e.g., tillage methods); monitoring the compliance of crop operations to EU regulations; and directives, e.g., "Farm to Fork" and European Green Deal [5-10]. The images remotely sensed from Unmanned Aerial Vehicles (UAVs) [3,11,12] or Remotely Piloted Aerial Systems (RPASs) [13], aircrafts [3] and satellites [5,14-19] are used as mapping tools in order to classify crops and examine their health and viability, as well as monitor crop operations.

Each image source has its advantages and disadvantages. In fact, even the use of UAV, combined with high-resolution images, can achieve high spatial accuracy; however, the missing standard procedures to estimate vegetation indexes make its use difficult. Instead, although satellite images have lower resolution, they have a periodicity depending on the revisit time of the satellite and the number of satellites in the constellation. On the other hand, the satellite is dependent on cloud level, as well as UAVs, but is not restricted by other weather factors negatively affecting UAV operations, i.e., wind. Moreover, if the farm or the study area is large, satellite imagery is a low-cost method compared to UAVs and ground-based robotic vehicles. Furthermore, a large image of the whole area is obtained at the same time: Sentinel-2 satellites have a spatial resolution of $10 \mathrm{~m}$ in the red and near-infrared bands, as well as a temporal resolution of five days from 07 March 2017, which could be enough to monitor a vineyard. Finally, the use of UAVs or aircrafts implies an initial investment, as well as having qualified personnel capable of setting up and piloting these devices and performing subsequent processing of the obtained data, while satellite imagery providers provide ready-to-work images and offers the possibility of consulting the images archive A threshold value slightly higher than five was been established: above such a scale size, images taken by satellite may be more convenient rather than those acquired by UAVs. However, these two image sources can be combined to contribute to the decision-making process as well as in vineyard management [18].

Therefore, if a UAV or aircraft is used for remote sensing of within-field crop and soil parameters, it is necessary to equip it with a multispectral camera and a GNSS (e.g., GPS, GLONASS and EGNOS) mobile receiver [20], as well as to use a proper testing protocol $[3,12,13]$.

This protocol can be highly simplified if satellites are used for the remote sensing of within-field crop and soil parameters [21].

Within remote sensing from satellites, an innovative instrument and method needed for implementing precision agriculture is the web-based platform AgroInsider [22].

AgroInsider is a Portuguese web-based platform providing subscribed customers with the possibility to use the images remotely sensed by the satellites Copernicus [23] Sentinel-1 (equipped with dual polarised radar systems or sensors) [24] and Sentinel-2 (equipped with optical multispectral sensors).

Two versions of this web-based platform are available: Agromap, designed for PC, and Smartag, designed for smartphones [22].

The Sentinel-2 mission comprises a constellation of two polar-orbiting satellites placed in the same sun-synchronous orbit, phased at $180^{\circ}$ to each other. It aims to monitor the spatial and temporal variability of land surface conditions [18,25-31].

Remote sensing from the satellite Copernicus Sentinel-2 is a technique that can be used for producing maps of within-field crop (e.g., plant vegetative vigour and leaf water content) and soil parameters (e.g., water content and soil structure). The interpretation of 
the images remotely sensed by this satellite must follow for developing a Decision Support System (DSS). The final aim is to produce spatially variable rate crop input application maps which must be adjusted in every crop season in order to become increasingly fitting to the crop needs.

Among several vegetation indexes that can be calculated, NDVI (Normalised Difference Vegetation Index) and NDWI (Normalised Difference Water Index) have some practical advantages. In fact, NDVI can be applied to evaluate the plant photosynthetic activity and, therefore, its vegetative vigour and soil coverage during growth phases, so that it is measured by optical sensors (e.g., Arvatec OptRx and Trimble GreenSeeker) for planning fertilisation [12,32-37] and irrigation. Therefore, NDVI mapping remains the most affordable way to easily and objectively obtain vineyard spatial information [3], as this index has proved to be a useful tool for monitoring crop yield [18] and table grape quality characteristics [14]. Moreover, NDWI can be applied to evaluate plant water stress and leaf water content during growth phases, so that irrigation can be monitored in near real-time in order to improve agriculture efficiency, especially in areas where meeting the plant need for water is more challenging [38].

The aim of this work is to produce spatially variable rate nitrogen fertiliser maps to be applied in two vineyard plots under study, as well as to understand when they should be fertilised or not according to their target crop yields in order to provide the highest economic and environmental benefits.

\section{Materials and Methods}

\subsection{Study Area}

During the first visit to the Sicilian vineyard farm "Chilometro7", located at a Longitude of $13^{\circ} 53^{\prime} 34^{\prime \prime}$, Latitude of $37^{\circ} 18^{\prime} 26^{\prime \prime}$ and Altitude of $634 \mathrm{~m}$. a.s.l. in the territory of Naro (Agrigento, Sicily, Italy), the main vineyard (Vitis vinifera L.) characteristics (e.g., vine varieties, fruit tree forms and plant distances) and the performed crop operations (e.g., fertilisation, green pruning and harvest) of two plots, less than $100 \mathrm{~m}$ far from each other, were monitored and noted:

(1) plot having an area of 1.75 ha ca., where the vine variety Syrah is cultivated, using the fruit tree form step-over espalier with plant distances of $2.5 \times 1 \mathrm{~m}$ (Figure 1);

(2) plot having an area of 1 ha ca., where the vine variety Nero d'Avola is cultivated, using the fruit tree form marquee with plant distances of $2.8 \times 2.8 \mathrm{~m}$ (Figure 2).

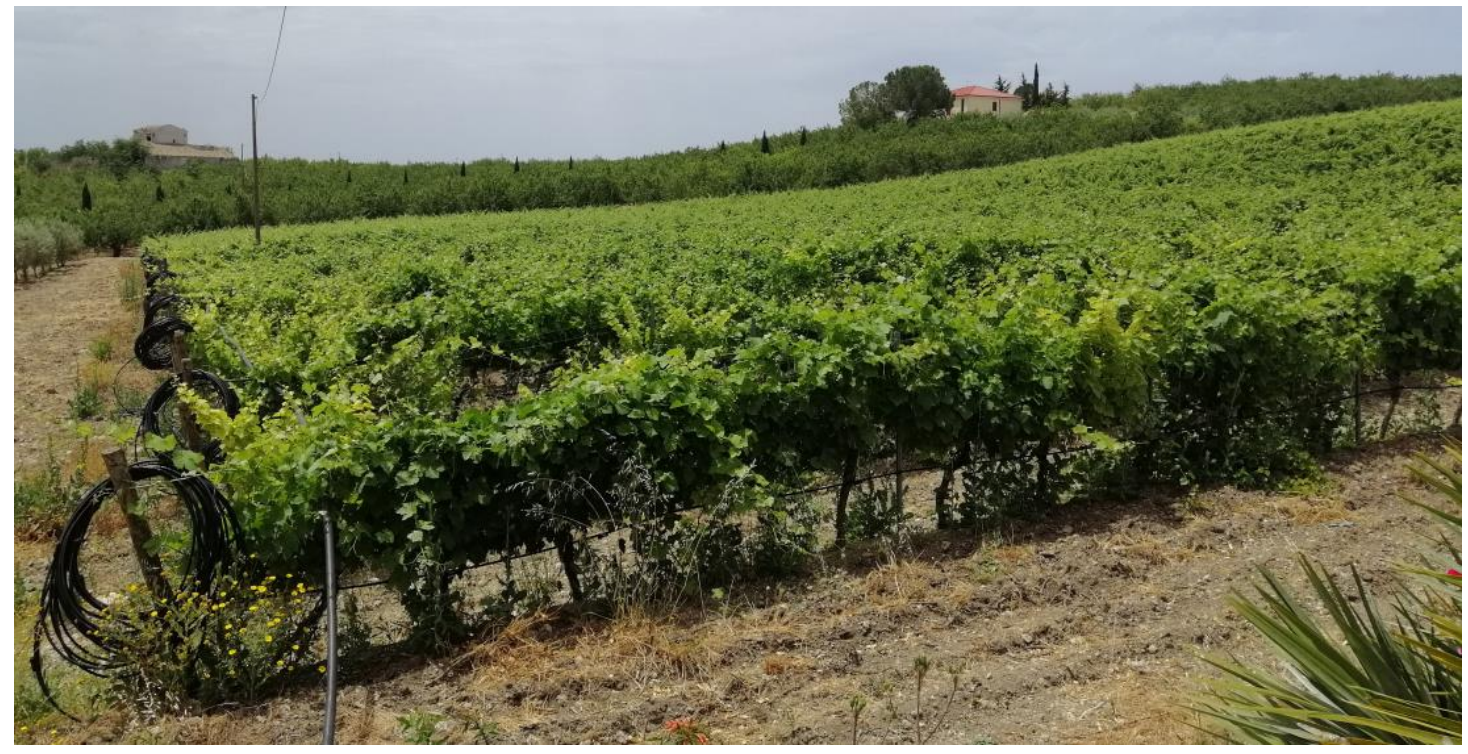

Figure 1. Vineyard plot (1.75 ha ca.) cultivated with the variety Syrah (step-over espalier fruit tree form). 


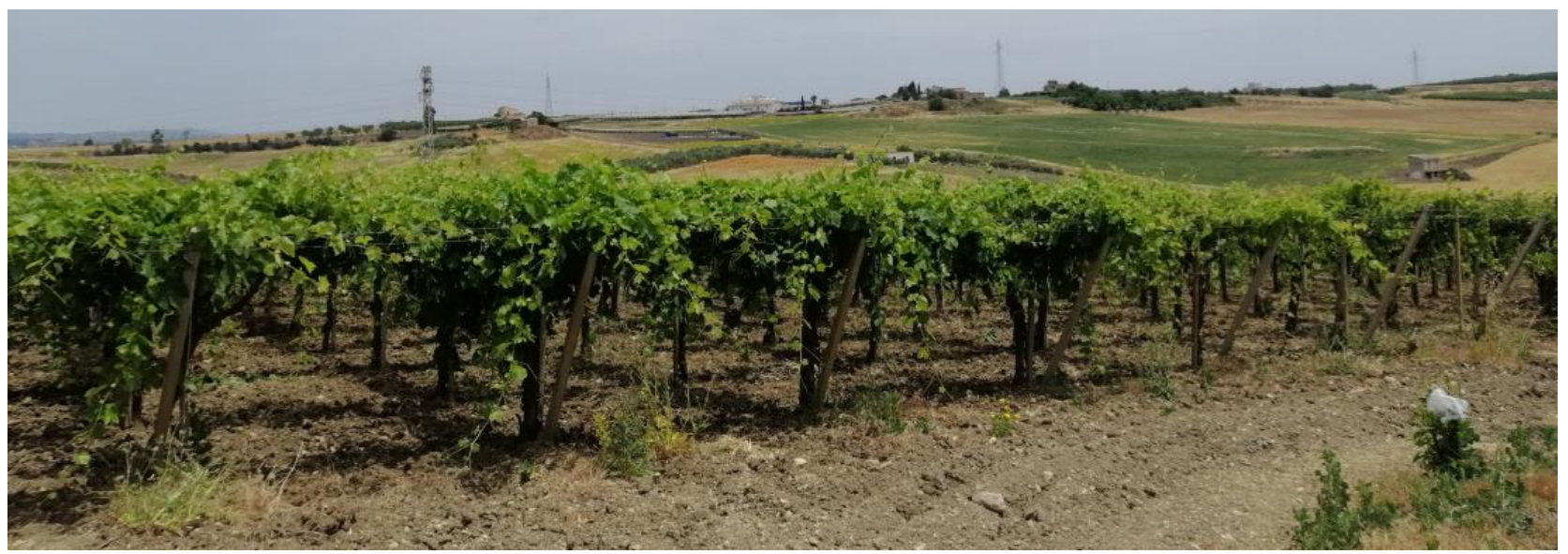

Figure 2. Vineyard plot (1 ha ca.) cultivated with the variety Nero d'Avola (marquee fruit tree form).

Table 1 shows the physical and chemical soil parameters of Syrah and Nero d'Avola plots.

Table 1. Physical and chemical soil parameters of Syrah and Nero d'Avola plots (from the soil analysis carried out in January 2021).

\begin{tabular}{|c|c|c|c|c|}
\hline Parameter & $\begin{array}{c}\text { Obtained Value } \\
\text { (Syrah) }\end{array}$ & $\begin{array}{l}\text { Obtained Value } \\
\text { (Nero d'Avola) }\end{array}$ & $\begin{array}{l}\text { Measurement } \\
\text { Unit }\end{array}$ & $\begin{array}{l}\text { Reference } \\
\text { Value }\end{array}$ \\
\hline Clay & 45 & 46 & $\%$ & 45 \\
\hline Loam & 29 & 28 & $\%$ & 18.5 \\
\hline Sand & 26 & 26 & $\%$ & 36.5 \\
\hline Total Nitrogen (Kjeldhal) & 1.25 & 1.10 & $\mathrm{~g} \mathrm{~kg}^{-1}$ & $1.03-6.50$ \\
\hline Organic matter (organic Carbonium $\times 1.72$ ) & 2.71 & 1.88 & $\%$ & $1.5-3.5$ \\
\hline Absorbable Phosporus $\left(\mathrm{P}_{2} \mathrm{O}_{5}\right)$ & 46.5 & 45.7 & ppm & $35.0-92.5$ \\
\hline Total Limestone & 3.4 & 5.4 & $\mathrm{~g} \mathrm{~kg}^{-1}$ & $10-15$ \\
\hline Active Limestone & 1.3 & 2.1 & $\%$ & $2-5$ \\
\hline $\mathrm{pH}$ (inside water) & 7.3 & 7.4 & - & $5.5-8.0$ \\
\hline Electrical Conductivity (EC) at $25^{\circ} \mathrm{C}$ (extract $\left.1: 5\right)$ & 0.45 & 0.44 & $\mathrm{mS} \mathrm{cm}{ }^{-1}$ & $0.1-1.0$ \\
\hline Cationic Exchange Capacity (CEC) & 17 & 18 & $\mathrm{mEq} 100 \mathrm{~g}^{-1}$ & $10-20$ \\
\hline Exchangeable Calcium $\left(\mathrm{Ca}^{2+}\right)$ & 3050 & 3020 & ppm & $3500-4500$ \\
\hline Exchangeable Magnesium $\left(\mathrm{Mg}^{2+}\right)$ & 176 & 155 & ppm & $250-400$ \\
\hline Exchangeable Sodium & 7 & 6 & ppm & $<300$ \\
\hline Exchangeable Potassium $\left(\mathrm{K}^{+}\right)$ & 323 & 321 & ppm & $250-500$ \\
\hline
\end{tabular}

According to the current spatially uniform rate vineyard management, fertilisation is carried out in Syrah plot during winter, e.g., between 14 and 24 February 2021, by applying the rate of $1143 \mathrm{~kg} \mathrm{ha}^{-1}$ of Fomet powder organic fertiliser (constituted by cattle and poultry manure converted into humus) (Table 2), followed by no irrigation. No green pruning was carried out in the Syrah plot.

Fertilisation is also carried out in the Nero d'Avola plot during winter, e.g., between 14 and 24 February 2021, by applying the rate of $1000 \mathrm{~kg} \mathrm{ha}^{-1}$ of the above organic fertiliser, followed by no irrigation. Green pruning was carried out only in the Nero d'Avola plot in June.

The grapes of Syrah and Nero d'Avola are harvested in different periods (e.g., 9 and 21 September 2021, respectively) and sold to the wine-making industry "Cummo Vini-Casa Vinicola Sicania", located in the territory of Canicattì (Agrigento, Sicily, Italy), for the production of two different brands of wine- "Desiderio" and "Nero d'Avola Bio", respectively. 
Table 2. Specifications of the powder organic fertiliser Fomet "Humus Vita Stallatico Super" applied to Syrah and Nero d'Avola plots (average contents).

\begin{tabular}{|c|c|c|}
\hline Parameter & Value & Measurement Unit \\
\hline Water & $22-26$ & $\%$ \\
\hline Organic matter (humus) & $38-45$ & $\%$ \\
\hline $\mathrm{pH}$ & $6-7$ & - \\
\hline Total Nitrogen & $3-4$ & $\%$ \\
\hline Phosphorus & $3-4$ & $\%$ \\
\hline Potassium & $3-4$ & $\%$ \\
\hline Boron & 25 & $\mathrm{mg} \mathrm{kg}^{-1}$ \\
\hline Magnesium & 1 & $\%$ \\
\hline Fulvic acids & 9 & $\%$ \\
\hline Humic acids & 10 & $\%$ \\
\hline Sulphur trioxide $\left(\mathrm{SO}_{3}\right)$ & 1 & $\%$ \\
\hline $\mathrm{C} / \mathrm{N}$ ratio & 7.3 & - \\
\hline Total aerobic bacteria & $2,164,000,000$ & units forming colony $\mathrm{g}^{-1}$ \\
\hline Total anaerobic bacteria & $1,715,000,000$ & units forming colony $\mathrm{g}^{-1}$ \\
\hline Raw proteins & $19-25$ & $\%$ \\
\hline Raw lipids & $2-3$ & $\%$ \\
\hline Raw fibre & $8-12$ & $\%$ \\
\hline Cationic Exchange Capacity (CEC) & $30-50$ & $\mathrm{mEq} 100 \mathrm{~g}^{-1}$ \\
\hline Specific weight & $0.5-0.6$ & $\mathrm{~kg} \mathrm{dm}^{-3}$ \\
\hline
\end{tabular}

\subsection{Satellite Image Sensing and Statistical Data Analysis}

It was possible to study and implement a protocol for converting the images remotely sensed by the satellite Copernicus Sentinel-2 into maps of within-field crop and soil parameters and then spatially variable rate crop input application maps.

It was first necessary to select the vegetation indexes to be remotely sensed by the satellite Sentinel-2, i.e., NDVI and NDWI, in order to produce maps of each vegetation index for each plot [27].

In fact, the plant vegetative vigour is expressed by NDVI, i.e., Normalised Difference Vegetation Index, which is defined as:

$$
N D V I=(\rho N I R-\rho R E D) /(\rho N I R+\rho R E D)
$$

where:

- $\quad \rho R E D$ is the radiance (in reflectance units) of a red channel near $0.66 \mu \mathrm{m}$; and - $\quad \rho N I R$ is the radiance (in reflectance units) of a near-IR channel around $0.86 \mu \mathrm{m}$ [39].

As NDVI relates to the reflectance in the red and near-infrared wavelengths, it is considered an indicator of vegetation growth and green biomass accumulation [36]. Different studies using optical remote sensing demonstrated the relationship between canopy reflectance and biomass production [37]. In fact, Johnson et al. [40] showed a significant correlation $\left(R^{2}=0.74\right)$ between NDVI and LAI (Leaf Area Index) in vines, even if this happens for LAI values lower than 3.

Instead, the plant leaf water content is expressed by NDWI, i.e., Normalised Difference Water Index, proposed by Gao [39] and using two near-IR channels centred at $0.86 \mu \mathrm{m} \mathrm{ca}$. and $1.24 \mu \mathrm{m}$ ca., respectively, for remote sensing of vegetation liquid water from space. NDWI is defined as:

$$
N D W I=\rho(0.86 \mu \mathrm{m})-\rho(1.24 \mu \mathrm{m}) / \rho(0.86 \mu \mathrm{m})-\rho(1.24 \mu \mathrm{m})
$$

where:

- $\quad \rho(\lambda)$ is apparent reflectance;

- $\quad \lambda$ is wavelength; and 
- $\quad \rho(\lambda)$ is equal to $\Pi \mathrm{L}(\lambda) /\left[\cos \left(\theta_{0}\right) \mathrm{E}_{0}(\lambda)\right]$, with $\mathrm{L}(\lambda)$ measured radiance, $\theta_{0}$, solar zenith angle and $\mathrm{E}_{0}(\lambda)$ solar irradiance above the earth atmosphere [39].

Sentinel-2 satellite NDVI is simply and accurately defined as:

$$
N D V I=(N I R-R E D) /(N I R+R E D)
$$

namely:

$$
N D V I=(B 8-B 4) /(B 8+B 4)
$$

where:

- $\quad$ NIR is near-infrared channel;

- $\quad$ RED is red channel;

- $\quad B 8$ is Band 8 in Sentinel-2 satellite (NIR); and

- $\quad B 4$ is Band 4 in Sentinel-2 satellite (RED).

Instead, Sentinel-2 satellite NDWI is simply and accurately defined as:

$$
N D W I=(N I R-M I R) /(N I R+M I R)
$$

namely:

$$
N D W I=(B 8-B 12) /(B 8+B 12)
$$

where:

- $\quad$ NIR is near-infrared channel;

- $\quad M I R$ is mide-infrared channel;

- $\quad B 8$ is Band 8 in Sentinel-2 satellite (NIR); and

- $\quad$ B12 is Band 12 in Sentinel-2 satellite (MIR).

In order to sense the NDVI related to vineyard farms, it is necessary to retrieve the satellite images taken during the phenological phases when the value of this vegetation index is supposed to change [36]:

1. before green pruning (May);

2. after green pruning (June);

3. before harvest (August); and

4. after harvest (September).

In fact, the plant vegetative vigour and the plant leaf water content maps of the two surveyed plots were studied during the above four phenological phases. It was possible to retrieve the satellite images including the two plots where the vine plants of Syrah cultivar and those of Nero d'Avola variety are cultivated, respectively.

Bottom-of-Atmosphere (BOA) reflectance values of Sentinel-2 data were obtained from ESA (European Space Agency) servers, taking into consideration Copernicus program. The image spatial resolution was $10 \mathrm{~m}$ for B4 and B8 bands, while it was $20 \mathrm{~m}$ for B12 band, as well as the temporal resolution was five days. The obtained images were atmospherically corrected by means of the Sen2Cor algorithm, while the ArcGIS 10.x (ESRI, Redlands, CA, USA) software was used.

Image statistical data (e.g., minimum, maximum, average, standard deviation, Coefficient of Variation of image pixels distribution) of both NDVI ("Plant") and NDWI ("Water"), from the beginning of April to the end of September 2021 were calculated. Therefore, the graphs of both indexes were plotted for the above period and each plot was divided into two management zones according to the calculated statistical data. 


\section{Results}

The results of this work, expressed by graphs and maps, based on Sentinel-2 data, are structured as follows:

- vegetative vigour;

- leaf water content;

- criterion for deciding the optimal fertilisation time;

- temporal variability; and

- $\quad$ spatial variability.

Table 3 and Figure 3 show the meteorological data in the surveyed area during the considered period (Sicilian Agrometeorological Information System, Sicilian Region-Department of Agricultural and Food Resources-Section Infrastructural Interventions).

Table 3. Meteorological data (average values of 10 days) logged by the station closest to the surveyed area, i.e., that located in Delia (Caltanissetta, Sicily, Italy), from the beginning of April to the end of October 2021 (Sicilian Agrometeorological Information System, Sicilian Region-Department of Agricultural and Food Resources-Section Infrastructural Interventions).

\begin{tabular}{cccc}
\hline Measurement Time Interval & $\begin{array}{c}\text { Average Daily Air } \\
\text { Temperature }\left({ }^{\circ} \mathbf{C}\right)\end{array}$ & $\begin{array}{c}\text { Maximum Daily Air } \\
\text { Temperature }\left({ }^{\circ} \mathbf{C}\right)\end{array}$ & $\begin{array}{c}\text { Minimum Daily Relative } \\
\text { Humidity }(\%)\end{array}$ \\
\hline 1-10 April 2021 & 11.56 & 17.58 & 45.8 \\
11-20 April 2021 & 11.18 & 16.81 & 47.5 \\
21-30 April 2021 & 15.73 & 22.29 & 44.7 \\
1-10 May 2021 & 17.84 & 24.4 & 33.1 \\
11-20 May 2021 & 17.96 & 24.8 & 27.1 \\
21-31 May 2021 & 19.53 & 26.99 & 26.91 \\
1-10 June 2021 & 20.13 & 27.24 & 30.6 \\
11-20 June 2021 & 22 & 30.08 & 27.5 \\
21-30 June 2021 & 29.34 & 38 & 16.5 \\
1-10 July 2021 & 27.32 & 34.67 & 21.8 \\
11-20 July 2021 & 24.37 & 31.3 & 31.5 \\
21-31 July 2021 & 27.71 & 35.25 & 19.91 \\
1-10 August 2021 & 29.07 & 37.14 & 19 \\
11-20 August 2021 & 27.87 & 35.22 & 26 \\
21-31 August 2021 & 24.32 & 31.38 & 31.73 \\
1-10 September 2021 & 21.3 & 28.19 & 44.9 \\
11-20 September 2021 & 22.71 & 29.93 & 34 \\
21-30 September 2021 & 22.31 & 28.64 & 44.8 \\
1-10 October 2021 & 17.47 & 23.57 & 55.3 \\
11-20 October 2021 & 14.22 & 20.03 & 51.3 \\
21-31 October 2021 & - & - & 74.18 \\
\hline
\end{tabular}

The total rainfall from 01 April 2021 to 31 October 2021 was $254.8 \mathrm{~mm}$.

\subsection{Vegetative Vigour}

In the graph of average NDVI (Figure 4), it is possible to observe a similar trend for both plots (i.e., vine cultivars). In fact, the plant vegetative vigour highly increases from April to June and decreases at the beginning of June, more so in the Nero d'Avola cultivar rather than the Syrah one, as a consequence of green pruning, carried out in this month only in Nero d'Avola plot-where it caused a reduction of vegetative vigour. Then, the vegetative vigour becomes almost constant between mid-June and the beginning of July and decreases in July, as the productive activity (i.e., grape ripening) is prevalent on the vegetative one and the high temperature causes plant water stress. Finally, the vigour increases in August, as a slightly lower temperature causes lower plant water stress. It suddenly decreases in September, because the rest period (i.e., plant senescence or low vegetative activity) starts before for Syrah cultivar (harvested on 9 September) and after for the Nero d'Avola variety (harvested on 21 September). 


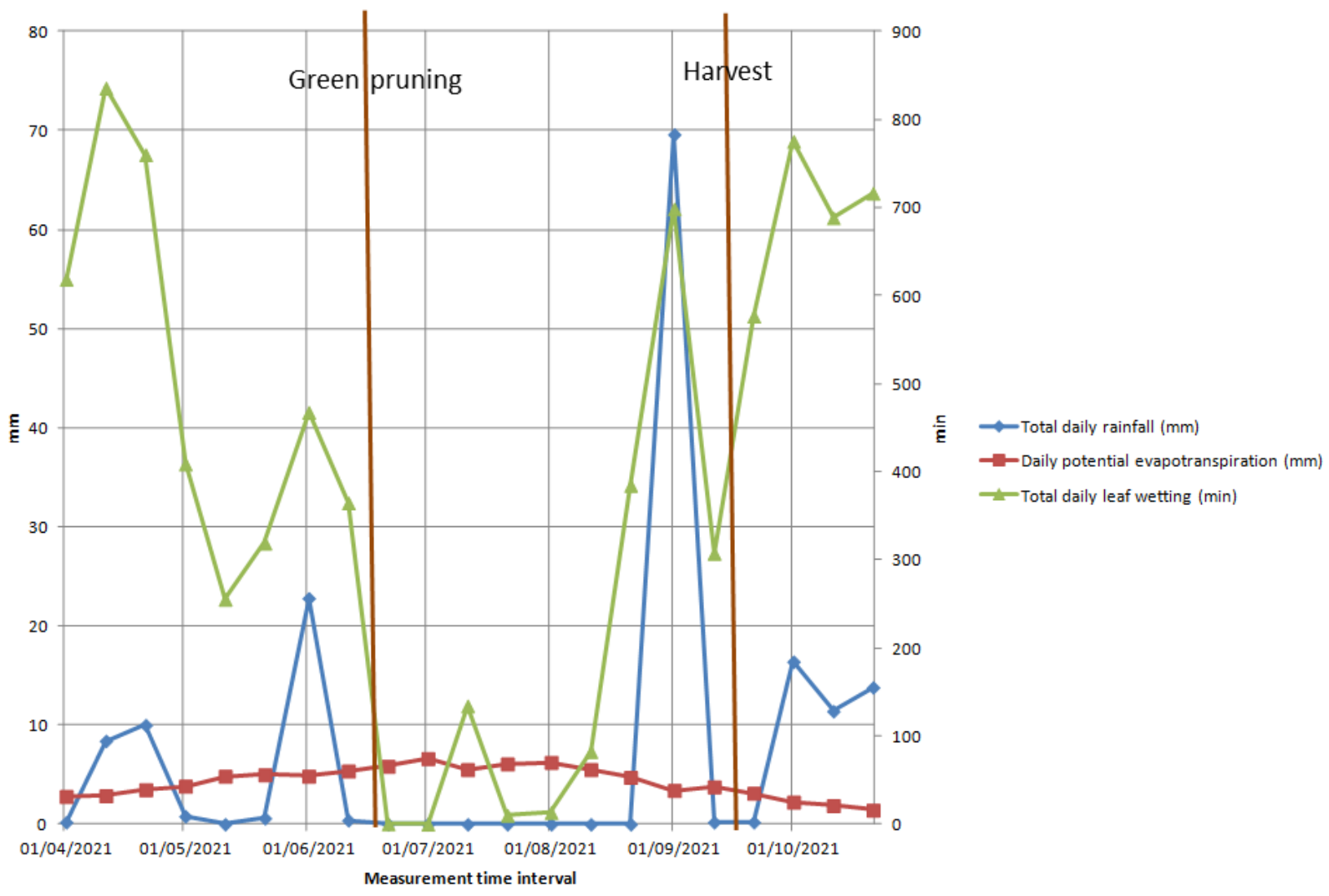

Figure 3. Meteorological data (average values of 10 days) logged by the station closest to the surveyed area, i.e., located in Delia (Caltanissetta, Sicily, Italy), from the beginning of April to the end of October 2021 (Sicilian Agrometeorological Information System, Sicilian Region-Department of Agricultural and Food Resources-Section Infrastructural Interventions).

However, the Nero d'Avola plot shows slightly higher values of NDVI rather than the Syrah one, from the mid of May to the end of September. The soil is similar in the two plots, except for organic matter content, which is 2.71 and $1.88 \%$ in the Syrah and Nero $\mathrm{d}^{\prime}$ Avola plots, respectively, and nitrogen content, which is 1.25 and $1.10 \mathrm{~g} \mathrm{~kg}^{-1}$ in the Syrah and Nero d'Avola plots, respectively (Tables 1 and 2). The difference in NDVI is due to the genetic characteristics of the cultivars and the fruit tree form. In fact, Nero d'Avola cultivar has a genetic attitude of higher vegetative vigour than the Syrah variety, as well as a marquee tree form that promotes higher vegetative vigour in the former plot rather than step-over espalier form in the latter one.

As the main objective of the considered vineyard farm is to maximise the crop yield (which, in 2021, resulted in $7.4 \mathrm{t} \mathrm{ha}^{-1} \mathrm{ca}$. in the Syrah plot and $11 \mathrm{t} \mathrm{ha}^{-1} \mathrm{ca}$. in the Nero $\mathrm{d}^{\prime}$ Avola plot), it is necessary to increase the crop yield of Syrah cultivar to levels similar to those of Nero d'Avola by implementing fertilisation in the right time and with the right rate; i.e., the rate required for satisfying the need of the species for nutrients such as nitrogen. In fact, if fertilisation is performed at the right time - not too late, when the soil water content is low-it is possible to prevent root burning and minimise the emissions of greenhouse gases (GHGs), e.g., nitrous oxides $\left(\mathrm{NO}_{\mathrm{x}}\right)$ from nitrate $\left(\mathrm{NO}_{3}\right)$. Moreover, if fertilisation is carried out at the right rate, it is possible to provide the vine plants with the nutrient amounts needed for vegetative activity well-balanced with productive activity. Thus, green pruning, which is aimed at reducing vegetative activity and, therefore, promoting productive activity, can be avoided in both plots in order to reduce production costs. 


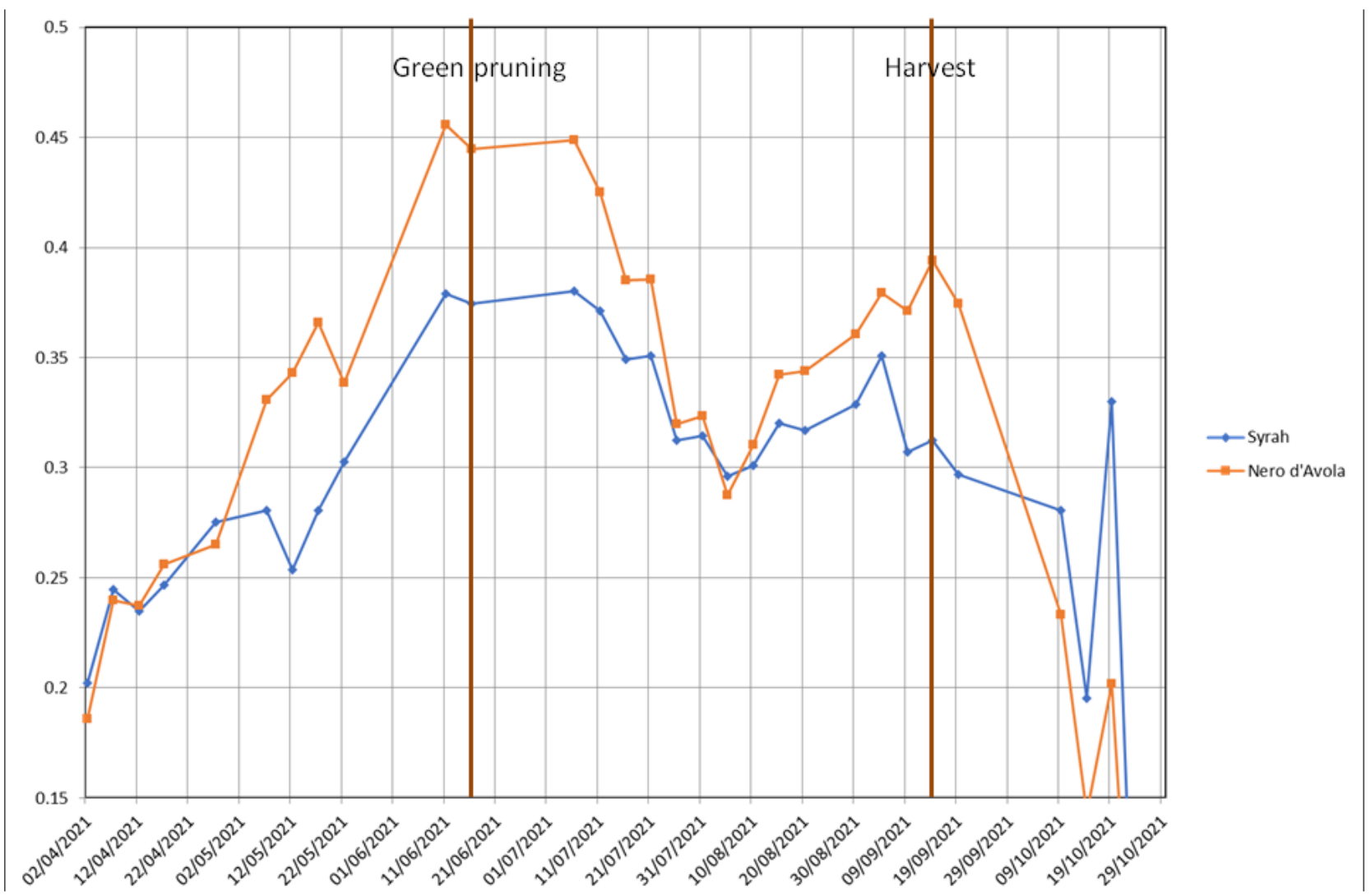

Figure 4. Graph of average NDVI (whose values can range from -1 to +1 ), from the beginning of April to the end of October 2021, for Syrah (blue line) and Nero d'Avola (orange line) plots.

\subsection{Leaf Water Content}

In the graph of average NDWI (Figure 5), it is possible to observe an almost identical trend for both plots (i.e., cultivars), even if Nero d'Avola cultivar has a higher plant leaf water content rather than Syrah during most of the surveyed period, meaning that the former has lower water stress rather than the latter. In fact, the plant leaf water content increases in the first half of April, due to the last rains of the season, and decreases in the second half of this month. Then, the leaf water content increases, decreases and increases in May-as a result of the rain distribution in this month-becomes almost constant in June, slightly decreases in July and increases in August. Finally, the leaf water content decreases in the first half of September and then suddenly increases because, even if the rest period starts, vine plants keep their leaves during winter but low temperature causes low transpiration.

\subsection{Criterion for Deciding the Optimal Fertilisation Time}

In the graphs of average NDVI and NDWI for the Syrah and Nero d'Avola plots (Figure 6), it is possible to observe that vegetative vigour suddenly increases from 12 May 2021, while the leaf water content suddenly increases until 12 April 2021. Thus, as fertilisation is aimed at supporting vegetative activity and must be performed when the soil water content and consequently plant leaf water content is high, the optimal time for this crop operation should have been 12 April 2021, above all because no irrigation was performed. In fact, in this case, a low soil water content would cause root burning and emissions of GHGs (i.e., nitrous oxides from nitrate). Therefore, the criterion for deciding the optimal fertilisation time is based on the comparison between NDVI and NDWI graphs for each plot. In fact, the optimal fertilisation time can be different if a farmer wants to promote vegetative vigour or fruit quality. However, in the case study, the objective is to produce 
the right amount of vineyard Leaf Area Content (LAC) that, for example, can maximise the crop yield. Even if different vine cultivars can have different needs for nutrients, they generally need higher amounts of available nutrients and water when plant LAC increases. In this period, if the plants cannot find the right amounts of nutrients and water in the soil to adsorb for growing, this is a factor limiting both vegetative and productive activities. Thus, plotting the curves of NDVI and NDWI for both cultivars (Figure 6) allows one to define the optimal fertilisation time, which is normally before the highest plant growth rate is achieved and is fundamental for providing the plants with the best nutritional soil conditions, i.e., amount of both nutrients and water to be adsorbed by the plants.

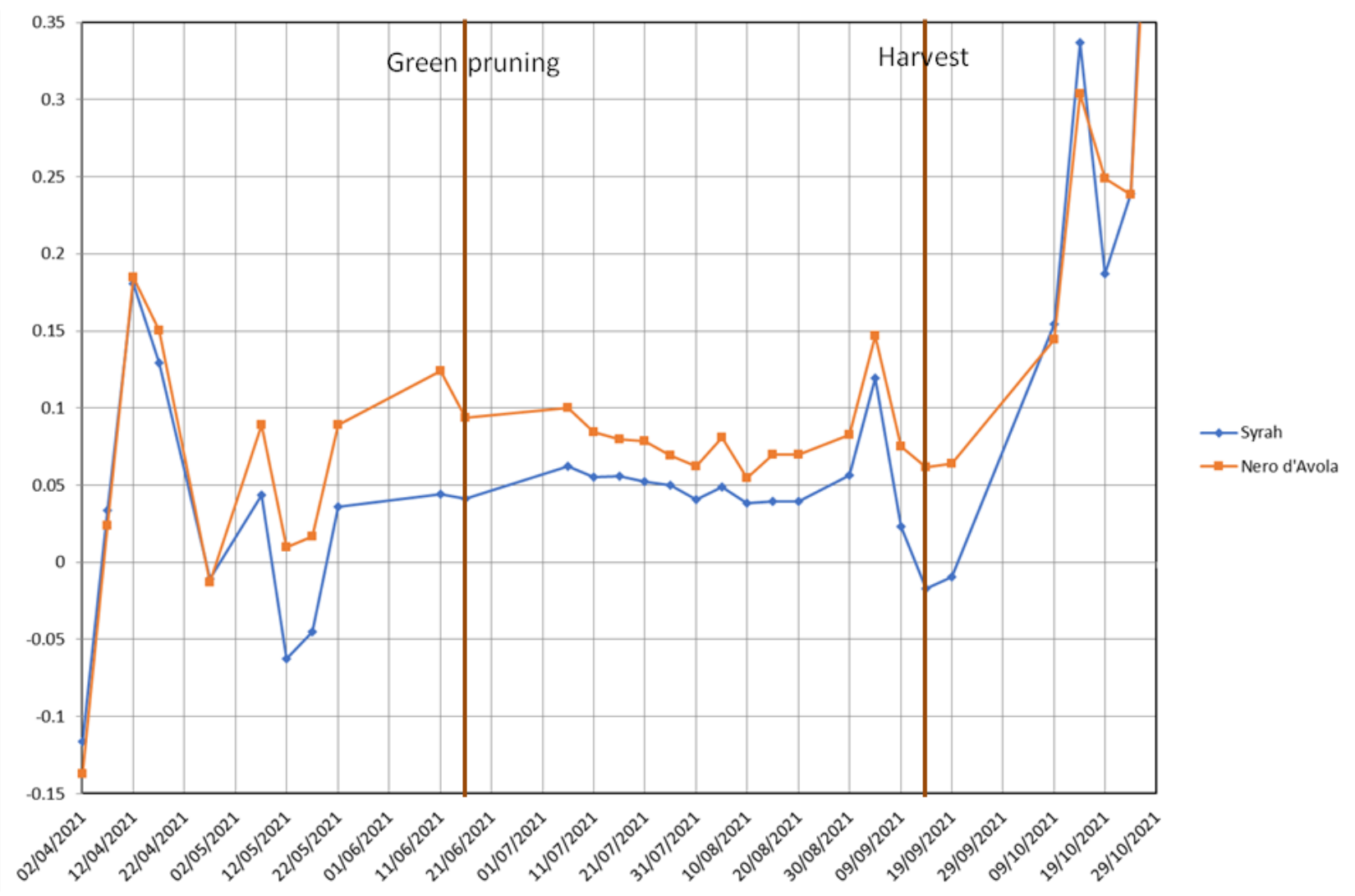

Figure 5. Graph of average NDWI (whose values can range from -1 to +1 ), from the beginning of April to the end of October 2021, for Syrah (blue line) and Nero d'Avola (orange line) plots.

\subsection{Temporal Variability}

The temporal variability of the within-field crop and soil parameters can be assessed by means of the Coefficient of Variation $(\mathrm{CV})$, which is a measure of relative variability, i.e., a standardised measure of the dispersion of a probability distribution or frequency distribution. It is defined as the ratio of the standard deviation $(\sigma)$ to the average $(\mu)$, often expressed as a percentage:

$$
C V=\sigma / \mu
$$

The temporal variability of vegetative vigour and leaf water content in both Syrah and Nero d'Avola plots was assessed based on the CV of NDVI and NDWI, respectively, from the beginning of April to the end of October 2021.

The CV of NDVI and NDWI of both the Syrah (Figure 7) and Nero D'Avola plots (Figure 8) show a high temporal variability during the four surveyed phenological phases (before green pruning, after green pruning, before harvest, after harvest). 


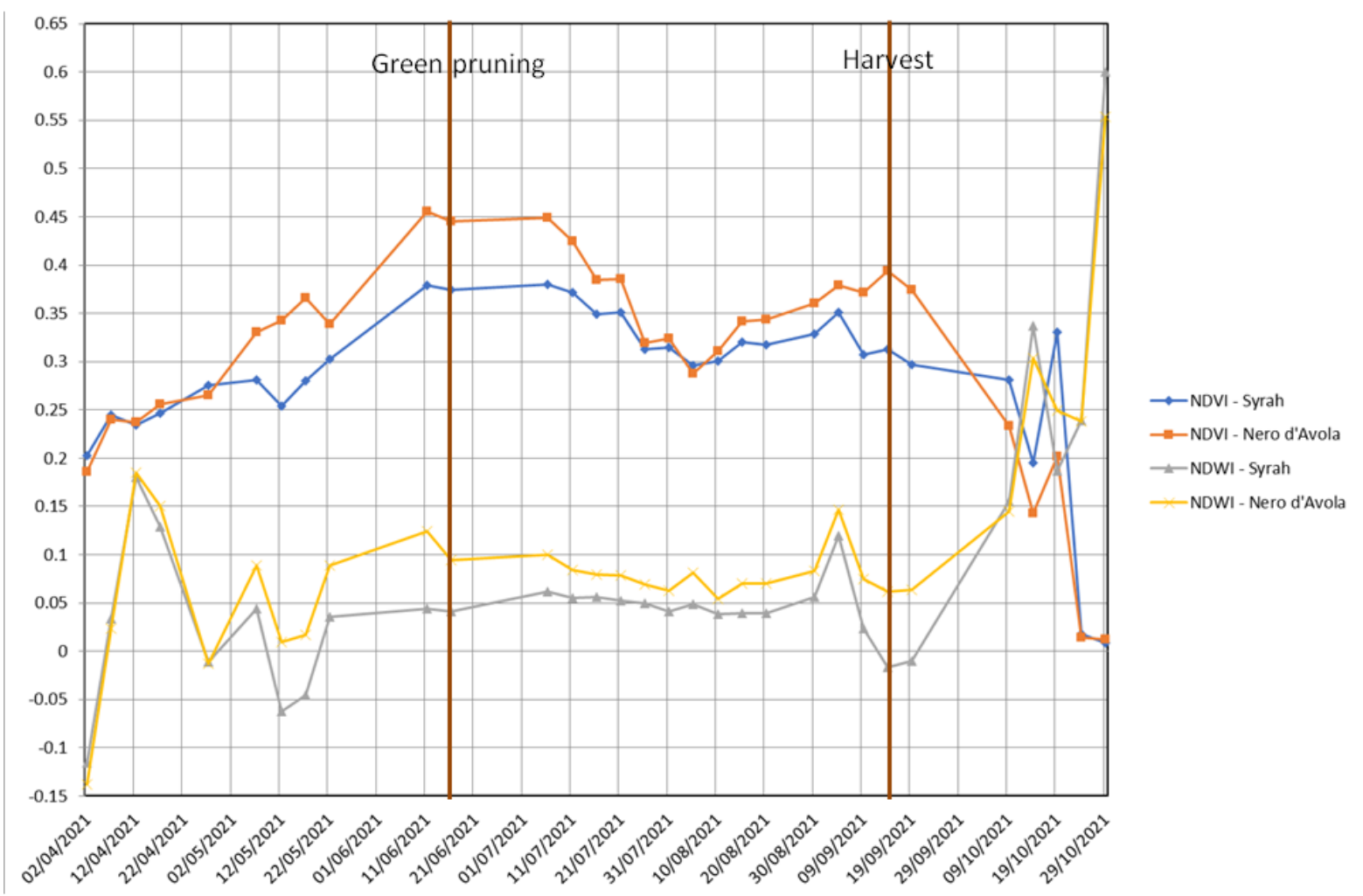

Figure 6. Graph of average NDVI and NDWI for Syrah and Nero d'Avola plots, from the beginning of April to the end of October 2021.

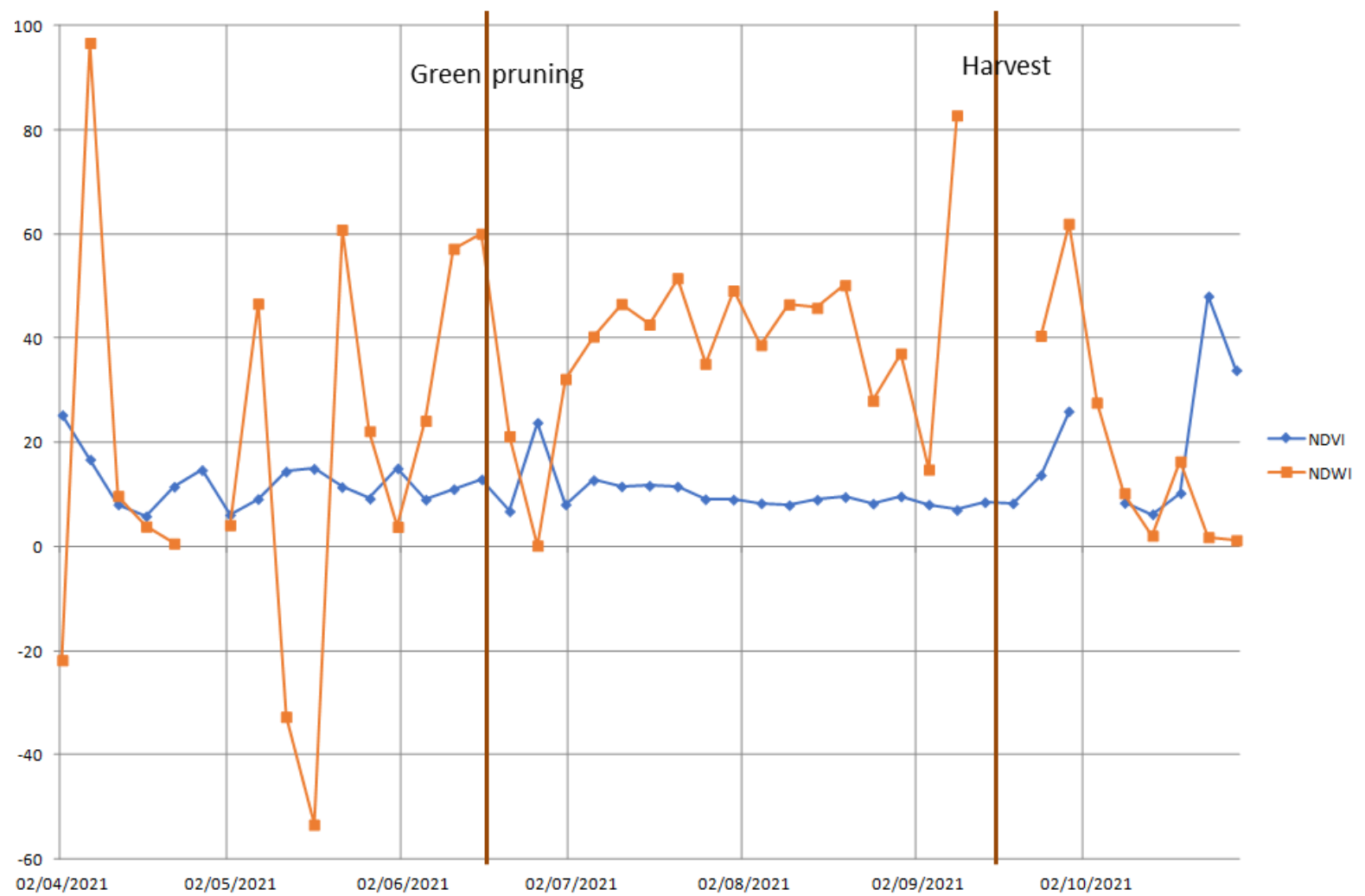

Figure 7. Graph of CV of NDVI (blue line) and NDWI (orange line) for Syrah plot, from the beginning of April to the end of October 2021. 


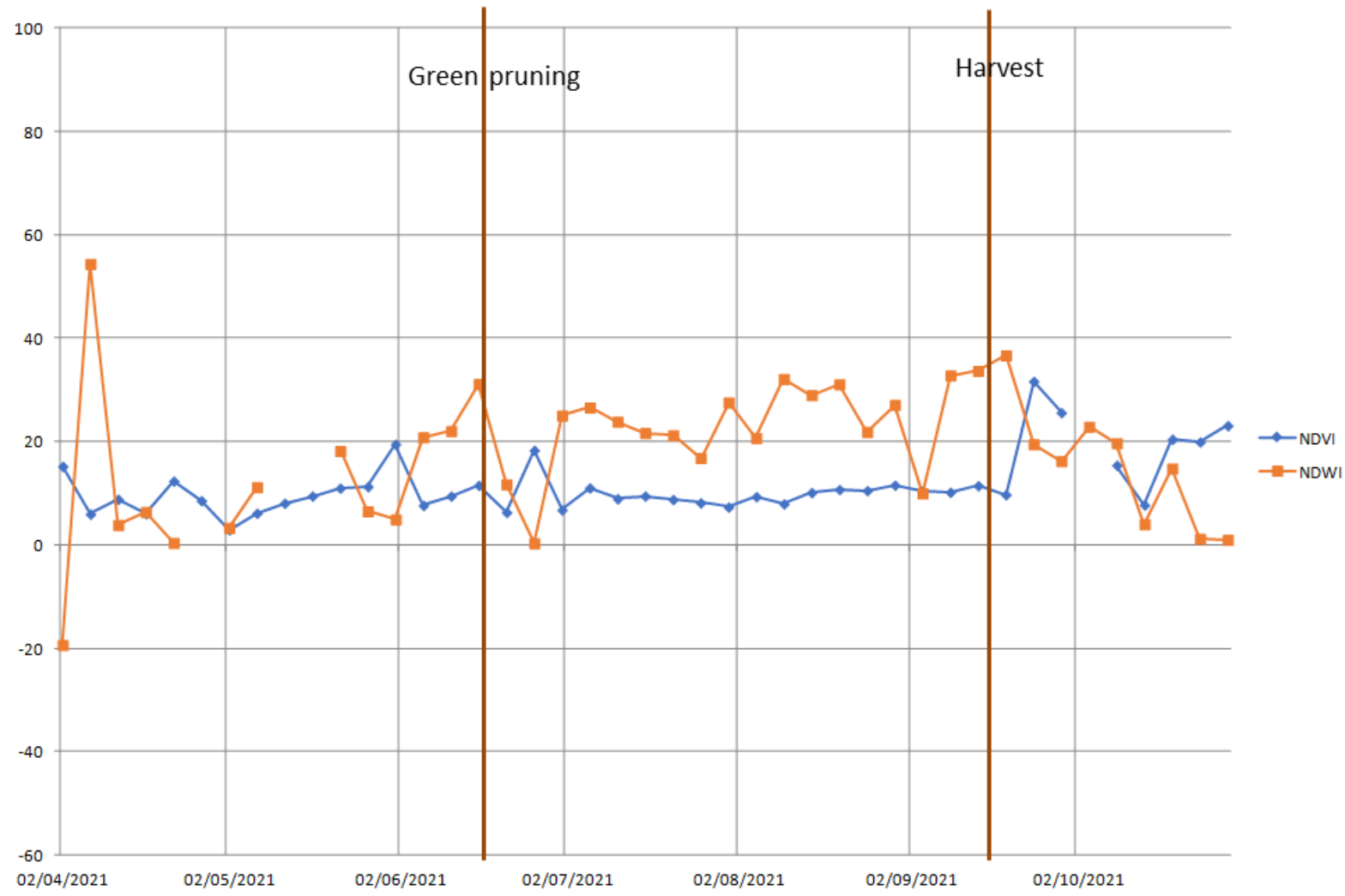

Figure 8. Graph of CV of NDVI (blue line) and NDWI (orange line) for Nero d'Avola plot, from the beginning of April to the end of October 2021.

Moreover, the Syrah plot shows a higher CV, above-average NDWI, than the Nero $\mathrm{d}$ 'Avola plot, meaning that the former has a higher variation of water stress than the latter.

\subsection{Spatial Variability}

The spatial variation of the NDVI in a plot can be measured using the Coefficient of Variation (CV) [41]. The threshold is set as the median value of the coefficients of all tested vineyard fields [42] at fertilisation time, i.e., 12 April 2021. Thus, from 06 February 2021 to 07 April 2021, the CV of NDVI ranges from a minimum value of $4.949 \%$ to a maximum of $27.859 \%$ for the Syrah plot, while it ranges from a minimum value of $3.976 \%$ to a maximum one of $17.395 \%$ for the Nero d'Avola plot. In this case, the median value is $19.28 \%$ for the Syrah plot, while it is $10.322 \%$ for Nero d'Avola one.

Therefore, a spatially variable rate fertiliser application should have been planned in both the plots, when the CV of NDVI was higher than $19.28 \%$ for the Syrah plot, i.e., on 2 April 2021, and higher than 10.322\% for the Nero d'Avola plot, i.e., on 2 April 2021 or 22 April 2021. Thus, according to the principles of precision agriculture, a higher rate should have been applied where the plant vegetative vigour was lower, while a lower rate should have been applied where the vigour was higher in order to have an uniform within-field vigour and, therefore, crop yield.

As fertilisation should have been carried out on 12 April 2021 and in a geo-referenced way, for both the plots, the map of the average NDVI of 7 April 2021-immediately before 12 April 2021 - should have been used to produce the spatially variable rate fertiliser map. Indeed, if an organic fertiliser should have been used rather than a chemical one, as was done in 2021, the map of 12 April 2021 should have been used so that over five days, the nutrients contained in this crop input could have been converted in soluble forms to be adsorbed by the plant roots.

Then, based on the maps of the average vegetative vigour and leaf water content of 12 April 2021, the spatially variable rate fertilisation maps, including two management 
zones, were produced for the Syrah (Figure 9) and Nero d'Avola (Figure 10) plots, by also considering the spatial and temporal image statistical data for each plot. In fact, some scientists, e.g., Bonilla et al. [3], discovered significant differences for the most part of the analysed traits of grape chemical composition between two areas; thus, they suggested two zones for practical differential management. Moreover, Allegro et al. [34] discovered significant differences in vegetative vigour between two areas; thus, they applied a fertiliser rate of $60 \mathrm{~kg} \mathrm{ha}^{-1}$ in the low-vigour management zone and another of $30 \mathrm{~kg} \mathrm{ha}^{-1}$ in the high-vigour zone.

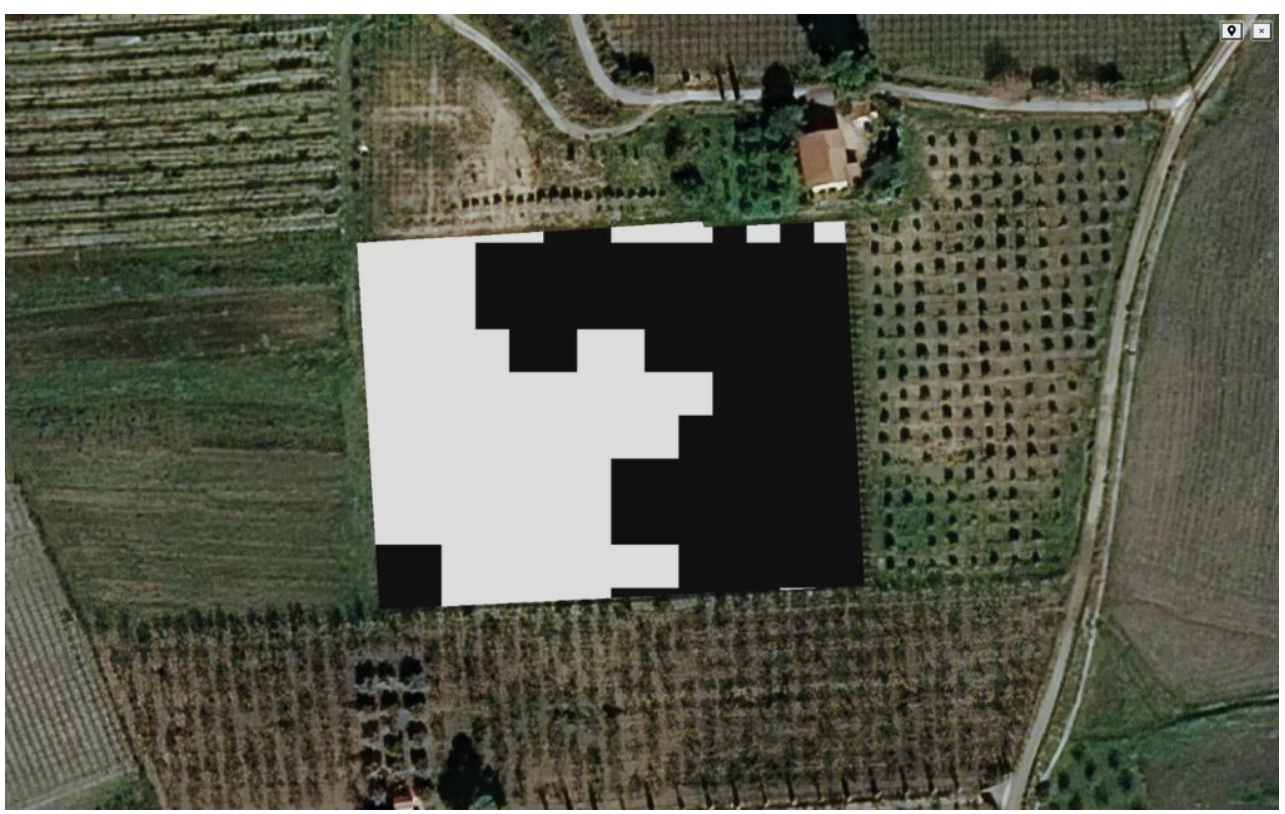

Figure 9. Spatially variable rate fertilisation map, including two management zones, for Syrah plot: the cells having higher NDVI and NDWI values are in black, while the cells having lower values of these indexes are in white.

Moreover, the above management zones could be used for soil sampling in order to determine the soil parameters, both chemical (e.g., water and nutrients contents) and physical (e.g., texture), in each zone.

Furthermore, the above vineyard management zones could allow to plan one of two harvest strategies, i.e., temporally variable harvest in the zones having different ripening periods, for the production of uniform quality grapes and therefore wine, or spatially variable harvest (by means of a grape harvester equipped with two hoppers) for the production of different quality grapes and therefore wines [1,2,43]. In fact, under a climate change scenario, it may be interesting to consider the NDVI zones for a selective harvest based on grape juice $\mathrm{pH}[3]$.

As another option, fertiliser rate can be associated with each range of the average NDVI shown in the map of 7 April 2021 (or 12 April 2021) in order to produce a spatially variable rate fertiliser map for each of the two surveyed plots by taking into account the best plant vegetative vigour/crop yield ratio. 


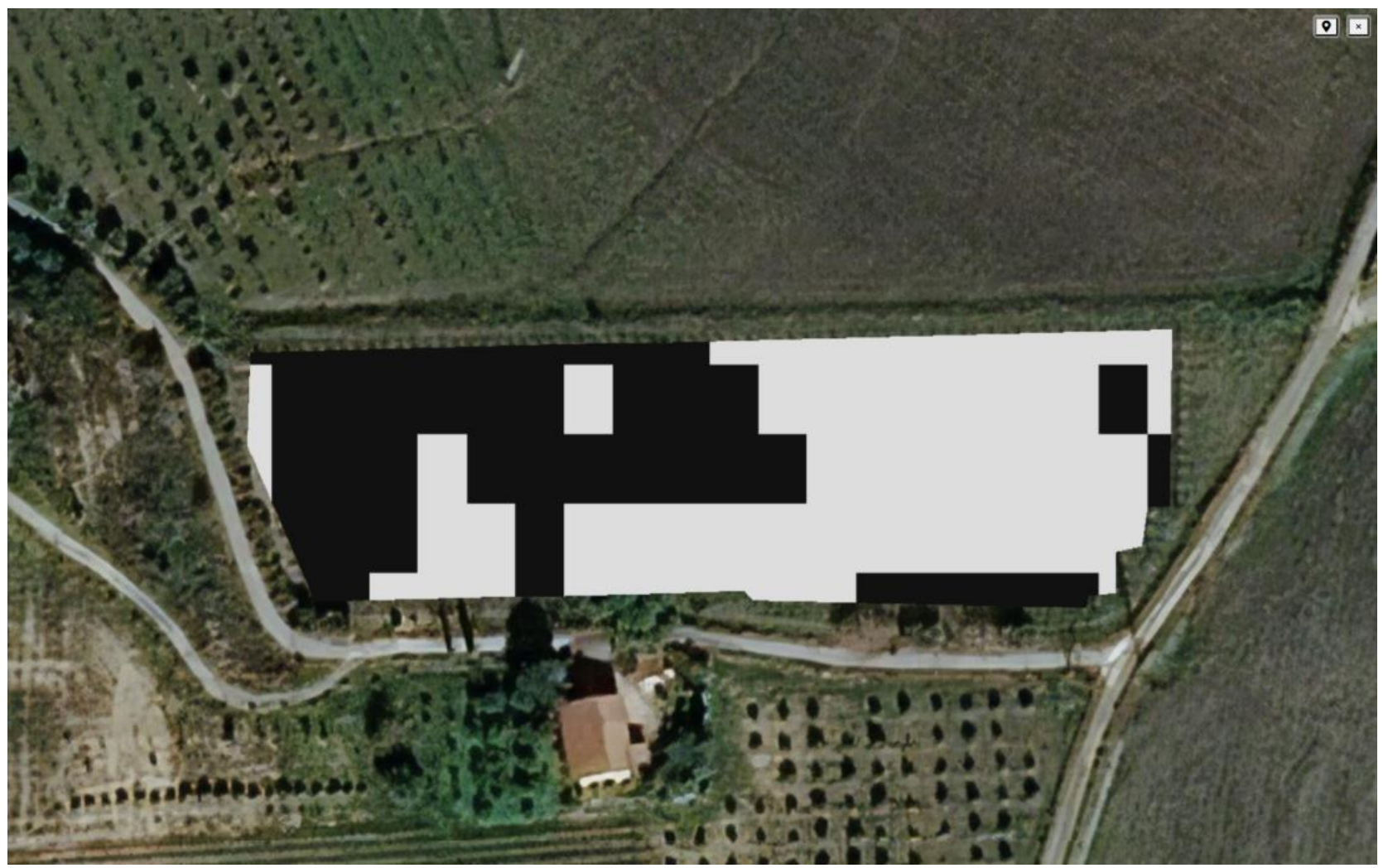

Figure 10. Spatially variable rate fertilisation map, including two management zones, for Nero d'Avola plot: the cells having higher NDVI and NDWI values are in black, while the cells having lower values of these indexes are in white.

\section{Discussion}

The Syrah variety has a much higher plant density (area of 1.75 ha, plant distances of $2.5 \times 1 \mathrm{~m}$, plant density of 7000 plants ha ${ }^{-1}$ ) when compared with Nero d'Avola (area of 1 ha, plant distances of $2.8 \times 2.8 \mathrm{~m}$, plant density of 1276 plants ha ${ }^{-1}$ ). By taking into account this difference in plant density, it would be normal that the Syrah variety had a higher NDVI during the whole year, as a consequence of the much higher plant density. Instead, the opposite is shown in Figure 4. Thus, in a dry (not irrigated) vineyard, a higher plant density determines a higher competition for resources (i.e., water and nutrients) among plants that, therefore, are less vigorous. However, a higher plant density (in the Syrah plot) determines a lower grape production per plant (1.06 vs. $8.62 \mathrm{~kg} \mathrm{plant}^{-1}$ ) and a lower crop yield ( 7.4 vs. $11 \mathrm{t} \mathrm{ha}^{-1}$ ), on average. Under the surveyed soil parameters and climate conditions, even if a higher plant density (in Syrah plot) decreases both the production per plant $\left(\mathrm{kg} \mathrm{plant}^{-1}\right)$ and crop yield $\left(\mathrm{t} \mathrm{ha}^{-1}\right)$, it reduces the vigour (expressed by a lower NDVI in Figure 4), so that no green pruning is needed and, finally, the production cost is reduced. Furthermore, as a lower vegetative vigour (in the Syrah plot) promotes the productive activity and both the production per plant and crop yield are lower, a higher quality of grapes and, therefore, wine, is expected.

As the Nero d'Avola cultivar has a higher plant leaf water content during most of the surveyed period (Figure 5) and therefore, more water stress rather than the Syrah cultivar, higher plant density increases plant competition for resources, e.g., soil water. In fact, water stress plays a key role in vineyard management, above all in dry (not irrigated) plots such as those under study. Thus, less water per plant (in the Syrah plot, having 7000 plants ha $^{-1}$ ) determines a lower vegetative vigour and root volume and, therefore, a lower soil nutrient adsorption, resulting in a lower NDVI.

The NDVI temporal evolution for the two surveyed cultivars differs from that found by other scientists. In fact, Vélez et al. [18], for the Verdejo cultivar, found a lower peak in 
July and a higher one in September, after harvest (instead of the highest peak found in June in this study). Moreover, Heemann Junges et al. [36] found, on average, a peak when the berries begin to swell in the second half of October (which, for climate conditions, is very similar to June in the boreal hemisphere), for the Chardonnay variety, and a peak when the berries touch each other in the first half of December (which, for climate conditions, is very similar to July-August in the boreal hemisphere), for the Cabernet Sauvignon variety. These differences express different benchmark curves for both cultivars, depending on genetic characteristics, and different climate conditions, depending on the year.

Very few scientists have also studied NDWI temporal evolution, such as BorgognoMondino et al. [25], who performed preliminary tests on table grape vineyards covered with polyethylene sheets, using Sentinel-2 free optical data, and compared their spectral response with that of similar uncovered vineyards in order to assess if a reliable spectral signal is detectable through the plastic cover. The maximum NDVI was obtained in the first half of September or in the first half of April, while the maximum NDWI was recorded in the first half of October or in the first half of April, according to the surveyed covered vineyard. Moreover, their results demonstrated that no significant limitation (for both NDVI and NDWI) was introduced by plastic sheets while monitoring the spectral behaviour of covered vineyards.

Based on the previous studies and this work, NDVI and NDWI can be monitoring tools of plant behaviour and health; they can be used for planning fertilisation, irrigation, water stress management, pest and disease control.

However, the interpretation of the maps remotely sensed from the satellite Sentinel-2 for DSS is the most difficult step of any precision viticulture platform for spatially variable rate vineyard management. The maps remotely sensed from the satellite Sentinel-2 must be compared to each other in order to find eventual correlations among different crops (e.g., yield, plant vegetative vigour, expressed by NDVI, and plant leaf water content, expressed by NDWI) and soil parameters. The final aim is the spatially variable rate application of crop inputs (e.g., fertiliser), in order to achieve more sustainable management, in terms of crop inputs and production cost optimisation, as well as in terms of environmental and climate footprints according to the European Green Deal objectives.

In fact, climate change has also affected vine physiology [19] and contributed to increasing the berry ripeness process. Therefore, wines present higher alcohol content and tend to have higher $\mathrm{pH}$. Generally, for most of the winemaking regions, the warming trend from the last decades to date has led to higher quality wines (with higher concentrations in anthocyanins and polyphenols), especially in the Northern regions. However, the average increase of $+2{ }^{\circ} \mathrm{C}$-forecasted by 2049 — should affect vine phenology, leading to high-temperature ripening processes [3].

\section{Conclusions}

This work demonstrates the usefulness of remote sensing as DSS for precision viticulture and traditional viticulture, i.e., for deciding if, when and how spatially variable rate fertiliser application must be performed in a field, according to the principles of precision agriculture. In fact, remote sensing can be used for:

- deciding if spatially variable rate fertiliser management must be performed in a field, based on the eventual within-field spatial variability of plant vegetative vigour;

- $\quad$ identifying the optimal fertilisation time, based on the comparison between the graph of plant vegetative vigour and that of plant leaf water content (also for spatially uniform rate fertilisation, within traditional viticulture); and

- determining the spatially variable fertiliser rate to be applied in each management zone, based on the within-field spatial variability of plant vegetative vigour.

Practically, the method of remote sensing tested in this work can be used to identify two or three levels of vegetative vigour inside each plot, e.g., high, medium and low. Then, the grapes harvested in the two or three different vigour level areas can be processed for producing different wines having different quality. 
However, the correlation between plant vegetative vigour and leaf water content, as well as that between crop yield and other crop and soil parameters, is still one of the challenges to be overcome in precision viticulture in order to produce spatially variable rate crop input application maps that can increasingly satisfy crop needs.

Author Contributions: Conceptualization, A.C. and J.R.M.d.S.; methodology, A.C. and J.R.M.d.S.; software, A.C. and J.R.M.d.S.; validation, J.R.M.d.S.; formal analysis, A.C. and J.R.M.d.S.; investigation, A.C.; resources, J.R.M.d.S.; data curation, A.C. and J.R.M.d.S.; writing—original draft, A.C. and J.R.M.d.S.; writing-review \& editing, A.C. and J.R.M.d.S.; visualization, A.C. and J.R.M.d.S.; supervision, J.R.M.d.S.; project administration, J.R.M.d.S.; funding acquisition, J.R.M.d.S. All authors have read and agreed to the published version of the manuscript.

Funding: This work was funded by the project "HIBA: HUB Iberia Agrotech".

Informed Consent Statement: Informed consent was obtained from all subjects involved in the study.

Acknowledgments: The authors of this work acknowledge: (i) Giovanni Fontana, manager of "Chilometro7" vineyard farm, for providing vineyard data; (ii) AgroInsider, for providing remote sensing data, graphs and maps used for spatially variable rate fertiliser management; (iii) Sicilian Agro-meteorological Information System, Sicilian Region-Department of Agricultural and Food Resources-Section Infrastructural Interventions, for providing meteorological data.

Conflicts of Interest: The authors declare no conflict of interest.

\section{References}

1. Bramley, R.G.V. Precision Viticulture: Managing vineyard variability for improved quality outcomes. In Precision Viticulture; Woodhead Publishing Limited: Cambridge, UK, 2010; Volume 12, pp. 445-480.

2. Bramley, R.G.V. 12-Precision Viticulture: Managing vineyard variability for improved quality outcomes. In Woodhead Publishing Series in Food Science, Technology and Nutrition, Managing Wine Quality, 2nd ed.; Reynolds, A.G., Ed.; Woodhead Publishing Limited: Cambridge, UK, 2022; pp. 541-586; ISBN 9780081020678. [CrossRef]

3. Bonilla, I.; de Toda, F.M.; Martínez-Casasnovas, J.A. Vine vigor, yield and grape quality assessment by airborne remote sensing over three years: Analysis of unexpected relationships in cv. Tempranillo. Span. J. Agric. Res. 2015, 13, e0903. [CrossRef]

4. Government of Canada: Remote Sensing Tutorials. Available online: https://www.nrcan.gc.ca/maps-tools-publications/satelliteimagery-air-photos/tutorial-fundamentals-remote-sensing/9309 (accessed on 27 October 2021).

5. Ammoniaci, M.; Kartsiotis, S.-P.; Perria, R.; Storchi, P. State of the art of monitoring technologies and data processing for precision viticulture. Agriculture 2021, 11, 201. [CrossRef]

6. Zhaoa, D.H.; Li, J.L.; Qi, J.G. Identification of red and NIR spectral regions and vegetative indices for discrimination of cotton nitrogen stress and growth stage. Comput. Electron. Agric. 2005, 48, 155-169. [CrossRef]

7. Zhu, Y.; Yao, X.; Tian, Y.-C.; Liu, X.-J.; Cao, W.-X. Analysis of common canopy vegetation indices for indicating leaf nitrogen accumulations in wheat and rice. Int. J. Appl. Earth Obs. Geoinf. 2008, 10, 1-10. [CrossRef]

8. Bagheri, N.; Ahmadi, H.; Alavipanah, S.K.; Omid, M. Multispectral remote sensing for site-specific nitrogen fertilizer management. Pesq. Agropec. Bras. Brasília 2013, 48, 1394-1401. [CrossRef]

9. Cammarano, D.; Fitzgerald, G.J.; Casa, R.; Basso, B. Assessing the Robustness of Vegetation Indices to Estimate Wheat $\mathrm{N}$ in Mediterranean Environments. Remote Sens. 2014, 6, 2827-2844. [CrossRef]

10. Elazab, A.; Ordónez, R.A.; Savin, R.; Slafer, G.A.; Araus, J.L. Detecting interactive effects of $\mathrm{N}$ fertilization and heat stress on maize productivity by remote sensing techniques. Eur. J. Agron. 2016, 73, 11-24. [CrossRef]

11. Carvajal-Ramírez, F.; Marques da Silva, J.R.; Agüera-Vega, F.; Martínez-Carricondo, P.; Serrano, J.; Moral, F.J. Evaluation of Fire Severity Indices Based on Pre- and Post-Fire Multispectral Imagery Sensed from UAV. Remote Sens. 2019, 11, 993. [CrossRef]

12. Reynolds, A.G.; Brown, R.; Jollineau, M.; Shemrock, A.; Kotsaki, E.; Lee, H.-S.; Zheng, W. Application of remote sensing by unmanned aerial vehicles to map variability in Ontario Riesling and Cabernet Franc vineyards. In Proceedings of the 11th International Terroir Congress, McMinnville, OR, Canada, 12 July 2016; pp. 1-7.

13. Rey-Caramés, C.; Diago, M.P.; Martín, M.P.; Lobo, A.; Tardaguila, J. Using RPAS Multi-Spectral Imagery to Characterise Vigour, Leaf Development, Yield Components and Berry Composition Variability within a Vineyard. Remote Sens. 2015, 7, 14458-14481. [CrossRef]

14. Anastasiou, E.; Balafoutis, A.; Darra, N.; Psiroukis, V.; Biniari, A.; Xanthopoulos, G.; Fountas, S. Satellite and Proximal Sensing to Estimate the Yield and Quality of Table Grapes. Agriculture 2018, 8, 94. [CrossRef] 
15. Fontana, D.C.; Melo, R.W.; Wagner, A.P.L.; Weberb, E.; Gusso, A. Use of remote sensing for crop yield and area estimates in Southern Brazil. In ISPRS (International Society for Photogrammetry and Remote Sensing) Archives, WG VIII/10 Workshop Proceedings 2006 "Remote Sensing Support to Crop Yield Forecast and Area Estimates", Stresa, Italy, 30 November-1 December 2006; Baruth, B., Royer, A., Genovese, G., Eds.; JRC (Joint Research Centre), Institute for the Protection and Security of the Citizen: Stresa (Verbano-Cusio-Ossola), Italy, 2013; Volume XXXVI.

16. Macedo, F.L.; Sousa, A.M.O.; Gonçalves, A.C.; Marques da Silva, J.R.; Mesquita, P.A.; Rodrigues, R.A.F. Above-ground biomass estimation for Quercus rotundifolia using vegetation indices derived from high spatial resolution satellite images. Eur. J. Remote Sens. 2018, 51, 932-944. [CrossRef]

17. Sousa, A.M.O.; Gonçalves, A.C.; Mesquita, P.; Marques da Silva, J.R. Biomass estimation with high resolution satellite images: A case study of Quercus rotundifolia. ISPRS J. Photogramm. Remote Sens. 2015, 101, 69-79. [CrossRef]

18. Vélez, S.; Rubio, J.A.; Andrés, M.I.; Barajas, E. Agronomic classification between vineyards ('Verdejo') using NDVI and Sentinel-2 and evaluation of their wines. Vitis 2019, 58, 33-38. [CrossRef]

19. Gatti, M.; Garavani, A.; Terron, A.; Parisi, M.G.; Bernizzoni, F.; Poni, S. Preliminary application of variable rate N-fertilization in the Colli Piacentini area. Internet J. Enol. Vitic. 2016, 5, 1-20. Available online: www.infowine.com (accessed on 28 December 2021).

20. Catania, P.; Comparetti, A.; Febo, P.; Morello, G.; Orlando, S.; Roma, E.; Vallone, M. Positioning accuracy comparison of GNSS receivers used for mapping and guidance of agricultural machines. Agronomy 2020, 10, 924. [CrossRef]

21. Meyers, J.M.; Dokoozlian, N.; Ryan, C.; Bioni, C.; Vanden Heuvel, J.E. A New, Satellite NDVI-Based Sampling Protocol for Grape Maturation Monitoring (Technical Note). Remote Sens. 2020, 12, 1159. [CrossRef]

22. AgroInsider: Agroinsider Web App. Available online: https:/ /agromap.agroinsider.com/ (accessed on 27 October 2021).

23. European Space Agency (ESA): Earth Online, Earth Observation Information Discovery Platform. Available online: https: / / earth.esa.int/eogateway (accessed on 27 October 2021)

24. Sánchez-Crespo, F.A.; Marques da Silva, J.R.; Gómez-Villarino, M.T.; Gallego, E.; Fuentes, J.M.; García, A.I.; Ayuga, F. Differential Interferometry over Sentinel-1 TopSAR Images as a Tool for Water and Tillage Soil Erosion Analysis. Agronomy 2021, 11, 2075. [CrossRef]

25. Borgogno-Mondino, E.; de Palma, L.; Novello, V. Investigating Sentinel 2 Multispectral Imagery Efficiency in Describing Spectral Response of Vineyards Covered with Plastic Sheets. Agronomy 2020, 10, 1909. [CrossRef]

26. The European Space Agency (ESA): Sentinel Online, Polarimetry. Available online: https://sentinels.copernicus.eu/web/ sentinel/user-guides/sentinel-1-sar/product-overview/polarimetry (accessed on 27 October 2021).

27. Government of Canada: Radar Polarimetry, Introduction to Polarization. Available online: https://www.nrcan.gc.ca/maps-toolspublications / satellite-imagery-air-photos/remote-sensing-tutorials/microwave-remote-sensing/radar-polarimetry/9275 (accessed on 27 October 2021).

28. Raiyani, K.; Gonçalves, T.; Rato, L.; Salgueiro, P.; da Silva, J.R.M. Sentinel-2 Image Scene Classification: A Comparison between Sen2Cor and a Machine Learning Approach. Remote Sens. 2021, 13, 300. [CrossRef]

29. Serrano, J.; Shahidian, S.; da Silva, J.M.; Paixão, L.; Calado, J.; Carvalho, M.D. Integration of Soil Electrical Conductivity and Indices Obtained through Satellite Imagery for Differential Management of Pasture Fertilization. AgriEngineering 2019, 1, 567-585. [CrossRef]

30. Serrano, J.; Shahidian, S.; da Silva, J.M.; Paixão, L.; Carreira, E.; Carmona-Cabezas, R.; Nogales-Bueno, J.; Rato, A.E. Evaluation of Near Infrared Spectroscopy (NIRS) and Remote Sensing (RS) for Estimating Pasture Quality in Mediterranean Montado Ecosystem. Appl. Sci. 2020, 10, 4463. [CrossRef]

31. Serrano, J.; Shahidian, S.; Paixão, L.; da Silva, J.M.; Morais, T.; Teixeira, R.; Domingos, T. Spatiotemporal Patterns of Pasture Quality Based on NDVI Time-Series in Mediterranean Montado Ecosystem. Remote Sens. 2021, 13, 3820. [CrossRef]

32. Serrano, J.; da Silva, J.M.; Shahidian, S.; Silva, L.L.; Sousa, A.; Baptista, F. Differential vineyard fertilizer management based on nutrient's spatio-temporal variability. J. Soil Sci. Plant Nutr. 2017, 17, 46-61.

33. Sozzi, M.; Bernardi, E.; Kayad, A.; Marinello, F.; Boscaro, D.; Cogato, A.; Gasparini, F.; Tomasi, D. On-the-go variable rate fertilizer application on vineyard using a proximal spectral sensor. In Proceedings of the 2020 IEEE, International Workshop on Metrology for Agriculture and Forestry (MetroAgriFor), Trento, Italy, 4-6 November 2020; pp. 343-347.

34. Allegro, G.; Martelli, R.; Pizziolo, A.; Pastore, C.; Valentini, G.; Pezzi, F.; Filippetti, I. Using canopy proximal sensors for variable rate fertilization in a Trebbiano Romagnolo vineyard. In Proceedings of the ISHS (International Society for Horticultural Science) 2021, International Symposium on Precision Management of Orchards and Vineyards, Bologna, Italy, 7 October 2021.

35. Zinkevičienè, R.; Jotautienè, E.; Juostas, A.; Comparetti, A.; Vaiciukevičius, E. Simulation of granular organic fertilizer application by centrifugal spreader. Agronomy 2021, 11, 247. [CrossRef]

36. Junges, A.H.; Fontana, D.C.; Anzanello, R.; Bremm, C. Normalized difference vegetation index obtained by ground-based remote sensing to characterize vine cycle in Rio Grande do Sul, Brazil, Índice de vegetação por diferença normalizada obtido por sensor remoto de superfície para caracterização do ciclo de videiras no Rio Grande do Sul, Brasil. Ciência E Agrotecnologia 2017, 41, 543-553.

37. Mazzetto, F.; Calcante, A.; Mena, A.; Vercesi, A. Integration of optical and analogue sensors for monitoring canopy health and vigour in precision viticulture. Precis. Agric. 2010, 11, 636-649. [CrossRef] 
38. Earth Observing System: Index Stack (NDVI, NDWI, NDSI). Available online: https:/ / eos.com/make-an-analysis/index-stack/ (accessed on 9 January 2022)

39. Gao, B.-C. NDWI-A normalized difference water index for remote sensing of vegetation liquid water from space. Remote Sens. Environ. 1996, 58, 257-266. [CrossRef]

40. Johnson, L.F. Temporal stability of an NDVI-LAI relationship in a Napa Valley vineyard. Aust. J. Grape Wine Res. $2003,9,96-101$. [CrossRef]

41. Pringle, M.J.; McBratney, A.B.; Whelan, B.; Taylor, J.A. A preliminary approach to assessing the opportunity for site-specific crop management in a field, using yield monitor data. Agric. Syst. 2003, 76, 273-292. [CrossRef]

42. Arnó, J.; Martínez-Casasnovas, J.A.; Moral, M.T. Assessing opportunities for selective winery vintage with a market-driven composite index. Cogent Food Agric. 2017, 3, 1386438. [CrossRef]

43. Comparetti, A. Precision Agriculture: Past, Present and Future. In Proceedings of the International Scientific Conference "Agricultural Engineering and Environment-2011", Key-Note Presentation. Akademija, Kaunas District, Lithuania, 22-23 September 2011; pp. 216-230. 